\title{
Expanding the links between Brazilian and British neurology
}

\author{
Andrew J. Lees
}

It is with great pleasure that I write this invited editorial to publicize the recently established exchange program between the "Academia Brasileira de Neurologia" and the "Association for British Neurologists".

More and more young Brazilian neurologists started to visit the National Hospital for Neurology and Neurosurgery from the mid nineteen seventies and during my training and following my appointment to the staff their passionate enthusiasm for their mother country infected me with a great desire to visit Brazil and see for myself. More than twenty five years ago Wagner Horta and Aroldo Bacellar invited me to a meeting in Bahia and I have been visiting twice a year ever since. The large number of Brazilian neurologists who have spent a period of training overseas and the increasing active participation of Brazilian opinion leaders at international meetings has helped to raise the overall standard of neurology enormously in a short period of time. This has also led to the building of robust and fruitful international collaborations for research in the neurosciences.

Many of the fellows who have come to Queen Square have gone on to become distinguished neurologists and continue to be collaborators. For example in the last two years I have published more than 20 papers co-authored by Brazilian neurologists. I have recently published two articles with Luiz Augusto Andrade (from São Paulo) on the contribution of Tretiakoff to the understanding of Lewy body pathology ${ }^{1,2}$. With Francisco Cardo- so I have recently described a new dystonia gene ${ }^{3}$ and conducted some work on Sydenhams chorea ${ }^{4,5}$. Egberto Barbosa has joined me in the International LRRK2 Consortium $^{6}$ and also in a series of articles on olfaction in parkinsonism ${ }^{7-9}$ lead by my Brazilian senior fellow Laura Silveira-Moriyama. In 2009 I have joined Helio Teive and his young disciple Renato $\mathrm{Mu}-$ nhoz in a research partnership which resulted in an abstract selected for oral presentation at the American Academy of Neurology last April ${ }^{10}$. We have also established joint fellowships between the Reta Lila Weston Institute of Neurological Studies and the Hopistal São Rafael in Salvador (lead by Aroldo Bacellar and Guilherme Valença) and UFRJ and Santa Casa in Rio (lead by Ana Rosso and Denise Nicaretta). These new collaborations will lead to further publications and clinical training programmes in movement disorders for promising young Brazilians.

In 2009, a formal agreement was made for an exchange program between the "Academia Brasileira de Neurologia" and the "Association for British Neurologists". The two learned societies agreed that every year each will sponsor a visiting professor to spend a fortnight in the other country and establish contact with researchers and clinicians in their areas of speciality. Upon completion of the visit, the successful recipients are expected to enrich their local institution by proposing ways to collaborate with teams in the other country and promote closer research links and lasting connections.
Andrew J. Lees

Reta Lila Weston Institute of Neurological Studies

UCL Institute of Neurology 1 Wakefield street, WC1N 1PJ, London UK

E-mail: a.lees@ion.ucl.ac.uk
INCREMENTANDO OS LAÇOS ENTRE A NEUROLOGIA BRASILEIRA E INGLESA

MD, PhD, Reta Lila Weston Institute of Neurological Studies, UCL Institute of Neurology. 


\section{REFERENCES}

1. Andrade LA, Selikhova M, Lees AJ. Konstantin N. Tretiakoff in Brazil: a historical perspective and discussion of his contribution to brazilian neuroscience. Arq Neuropsiquiatr 2009;67:322-327.

2. Lees AJ, Selikhova M, Andrade LA, Duyckaerts C. The black stuff and Konstantin Nikolaevich Tretiakoff. Mov Disord 2008;23:777-783.

3. Camargos S, Scholz S, Simon-Sanchez J, et al. DYT16, a novel young-onset dystonia-parkinsonism disorder: identification of a segregating mutation in the stress-response protein PRKRA. Lancet Neurol 2008;7:207-215.

4. Church AJ, Dale RC, Cardoso F, et al. CSF and serum immune parameters in Sydenham's chorea: evidence of an autoimmune syndrome? J Neuroimmunol 2003;136:149-153.

5. Church AJ, Cardoso F, Dale RC, Lees AJ, Thompson EJ, Giovannoni G. Antibasal ganglia antibodies in acute and persistent Sydenham's chorea. Neurology 2002:59:227-231.

6. Healy DG, Falchi M, O'Sullivan SS, et al. Phenotype, genotype, and worldwide genetic penetrance of LRRK2-associated Parkinson's disease: a case-control study. Lancet Neurol 2008;7:583-590.

7. Silveira-Moriyama L, Petrie A, Williams DR, et al. The use of a color coded probability scale to interpret smell tests in suspected parkinsonism. Mov Disord 2009;24:1144-1153.

8. Silveira-Moriyama L, Guedes LC, Kingsbury A, et al. Hyposmia in G2019S LRRK2-related parkinsonism: clinical and pathologic data. Neurology 2008;71: 1021-1026.

9. Silveira-Moriyama L, Carvalho MJ, Katzenschlager R, et al. The use of smell identification tests in the diagnosis of Parkinson's disease in Brazil. Mov Disord 2008;23:2328-2334

10. Munhoz RP, Teive HA, Eleftherohorinou H, Coin LJ, Lees AJ, Silveira-Moriyama L. Can motor features of Parkinson's disease be used to predict occurrence of non-motor symptoms of the disease? Scientific Platform Session 5SS.023.2010 American Academy of Neurology Annual Meeting. Toronto, April $10^{\text {th }}-17^{\text {th }}, 2010$ 